\title{
Undead again
}

\section{How sweet the taste of freedom.}

\section{Ken MacLeod}

It's 2045 and I'm still a vampire. Damn.

The chap from Alcor UK is droning through his orientation lecture. New age of enlightenment, new industrial revolution, many changes, take some time to adjust, blah blah blah. I'm only half-listening, being too busy shifting my foot to keep it out of the beam of direct sunlight creeping across the floor, and trying not to look at his neck.

I feel like saying: I've only been dead 40 years, for Chr ... for crying out loud. I saw the first age of enlightenment. I worked nights right through the original Industrial Revolution. I remember being naive enough to get excited about mesmerism, galvanism, spiritualism, socialism, Röntgen rays, rationalism, radium, mendelism, Marconi, relativity, feminism, the Russian Revolution, the bomb, nightclubs, feminism (again), Apollo 11, socialism (again), the fall of Saigon and the fall of the Wall.

The last dodgy nostrum I fell for was cryonics.

So don't give me this futureshock shit, sunshine. The most disconcerting thing I've come across so far in 2045 is the latest ladies' fashion: the old sleeveless mini-dress. The ozone hole has been fixed, and folk are frolicking in the sun. I hug myself with bare arms, and slide the castored chair back another inch.

Under the heel of my left wrist, I feel the thud of my regenerated heart. It beats time to the artery visible under the tanned skin of the resurrection man's neck. The rest of my nature is unregenerate. I feel somewhat thwarted. This is not, this is definitely not, what I died for. And it seemed such a good idea at the time.

It always does.

By 1995 we thought we had a handle on the thing. It's a virus. In all respects but one, it's benign: it prevents ageing and stimulates regeneration of any tissue damage short of, well, a stake through the heart. But it has a very low infectivity, so it takes a lot of mingling of fluids to spread. Natural selection has worked that one hard. Hence the unfortunate impulses. And by 1995, I can tell you, I was getting pretty sick of them. I cashed in my six Scottish Widows life insurance policies (let's draw a veil over how I acquired them), signed up for cryonic preservation in the event of my death, and after a discreet ten years, met an unfortunate and bloody end at the hand of the coven senior, Kelvin.

"You'll thank me later," he said, just before he pushed home the point.

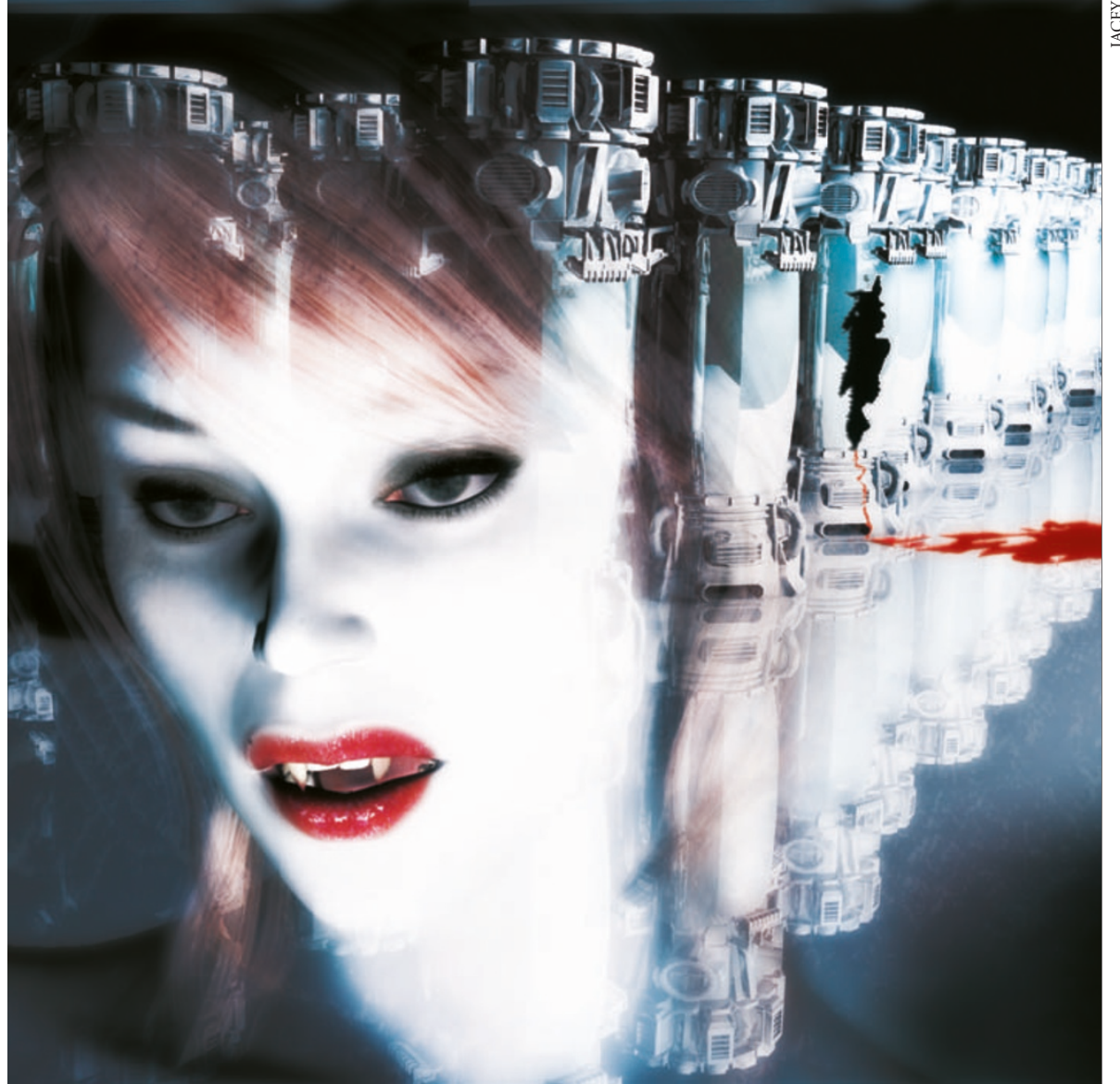

"See you in the future," I croaked.

The last thing I saw was his grin. That, and the pavement below the spiked railings beside the steps of my flat. A tragic accident. The coroner, I just learned, blamed it on the long skirt. Vampires - always the fashion victims.

I leave the orientation room, hang around until dusk under the pretext of catching up with the news, and go out and find a vintage clothes shop. I walk out in Victorian widow's weeds. They fit so well I suspect they were once mine.

"It didn't work," I tell Kelvin.

He sips his bloody mary and looks defensive. "It did in a way," he says. "There are no viruses in your blood."

That word again. I look away. We're in some kind of goth club, which covers for the mode but doesn't improve my mood.

"So why do I still feel ... hungry?"

"Have a tapas," he says. "But seriously ... the way we figure it, the virus has to have transcribed itself into our DNA. So the nanotech cell-repair just replicates it without a second thought."

"So we're stuck with it," I say. "Living in the dark and every so often..."

"Not quite," he says. "Now it's been estab- lished that cryonics really does work, there's been a whole new interest in a very old idea..."

The coffin lid opens. Kelvin's looking down, as I expect. The real shock is the light, fullspectrum and warm. It feels like something my skin has missed for centuries. I sit up, naked, and bask for a moment.

The overhead lights reproduce the spectrum of Alpha Centauri, which is where we're going. The whole coven is here, all 13 of them, happier and better fed than I've ever seen them. It's taken us a lot of planning, a lot of money, and a lot of lying to get here, but we're on our way.

"Welcome back," says Kelvin. He grins around at the coven.

"Let's thaw one out for her," he says. "She must be hungry."

As far as I can see stretch rows and rows of cryonic coffins containing interstellar colonists in what they euphemistically call cold sleep. Thousands of them.

Enough to keep us going until we reach that kinder sun.

Ken MacLeod's next book is Learning the World. His latest, Newton's Wake, is just out in Orbit paperback. He lives in West Lothian, Scotland. 